\title{
Should We Genetically Engineer Hogs?
}

\author{
Gary Comstock \\ lowa State University
}

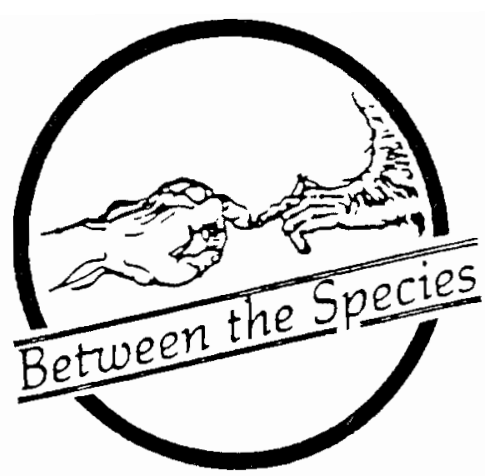

Editors' Note: The following paper by Professor Comstock and commentary by Professor Detmer were presented at the Eastern Division meetings of the Society for the Study of Ethics and Animals, held in New York City, New York, December, 1991.

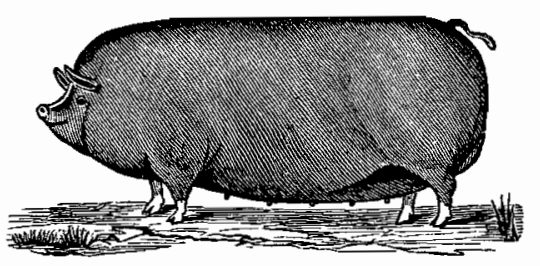

Should we use recombinant DNA techniques to create pigs genetically engineered to suit the preferences of fanners and consumers?

In 1982, scientists injected a rat growth hormone gene into the chromosome of a mouse. The resultant animal expressed the rat gene and quickly grew to twice its parents' size. ${ }^{1}$ In 1985, researchers at the United States Department of Agriculture hoped to attain similar results by inserting a human growth hormone gene into the chromosome of a pig. At the Agricultural Experiment Station in Beltsville, Maryland, experimenters successfully microinjected the piece of DNA encoding the production of human somatotropin into the nucleus of a fertilized pig egg. The extracted embryo was reimplanted into a sow's uterus; the pregnant animal came to term; and the first piglet in history with a human gene was born.

The Beltsville research program was not aimed at producing hogs twice the size of their parents but at producing more cost effective swine, pigs that would convert grain into lean meat faster than their parents while eating proportionately less grain. Such animals would be a boon to certain sectors of the agricultural economy, including most of the pork industry, some

hog farmers, and many meat consumers. The industry might cut costs by slaughtering fewer animals per pound of meat; farmers might reduce expenditures on feedgrains while continuing to sell the same amount of pork; and consumers might benefit from industry and farm savings passed on to them at the meat counter.

Nineteen transgenic swine lived through birth and into maturity. Several expressed elevated levels of the growth gene, but none grew more quickly or to greater size than their counterparts in the control group. ${ }^{2}$ However, many suffered from "deleterious pleiotropic effects," medical problems not afflicting the controls. ${ }^{3}$ Those animals developed abnormally and exhibited deformed bodies and skulls. Some had swollen legs; others had ulcers, crossed eyes, renal disease, or arthritis. ${ }^{4}$ Many seemed to suffer from decreased immune function and were susceptible to pneumonia. ${ }^{5}$ All were sterile. Later, researchers concluded that if transgenic swine were to be produced as successfully as transgenic mice, "better control of transgene expression, a different genetic background, or a modified husbandry regimen" would be required. ${ }^{6}$ Further experiments are underway.

Is the research program at Beltsville morally justified? Your answer will probably turn on your answer to three related questions. Do you think individual adult, nonhuman mammals have interests, in a morally relevant sense? If so, do you think it is

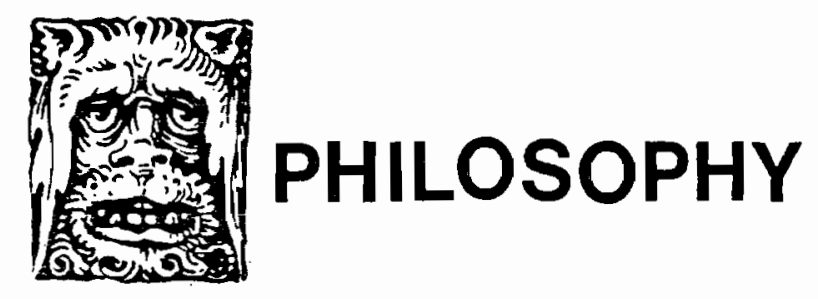


prima facie wrong, in the same way if not to the same degree, to deprive an animal of living conditions in which its basic biological needs can be met, just as it is prima facie wrong to deprive a human of living conditions in which its basic biological needs can be met? That is, do you think we should presume that deprivation is wrong unless we have reason to believe otherwise? Finally, do you think efficient production of livestock is an important social value?

Take the last question first. New and more efficient techniques for the production of market hogs could have substantial economic benefits, including a national hog population bred to convert feed into meat with great efficiency; hog breeders, farrowers, finishers, and consumers reaping financial benefits from the animals' efficient digestive tracts; and comparative economic advantages for American farmers facing competition from other countries. Notice that the gain in social utility here is not simply a gain in productivity but a gain in the efficiency of the use of resources, including human and plant resources as well as animal resources. Depending on how heavily you weigh such gains, you might believe the gains will outweigh the costs associated with the suffering of the nineteen transgenic swine.

But will they? To answer this question we must decide how much weight to assign to the animals' pain.

Start with an easier case. Suppose the experimental animals in question were human beings. Imagine that the only way to achieve the financial gains was to transfer swine growth hormone genes into fertilized human embryos, implant the embryos in women, bring the embryos to term, raise the resultant nineteen children to maturity, and then transfer the children's somatotropin genes back into the swine. Suppose further that the children in question had sickly malformed bodies analogous to the bodies of the Beltsville hogs. Clearly, the social benefits in this case, even if they were dramatic and sustained, could not be permitted to outweigh the costs. Any who would entertain the possibility that the pain and suffering of children may be justified by gains in economic efficiency of pork production are morally callous, or worse. We should not bring children into the world to use as means to economic ends, so experimenting on human embryos, without knowing what effects the procedures will have on the children the embryos will become, is at least irresponsible.

We should not approve a line of reasoning that would justify the production of Beltsville humans because of economic gains in agricultural production efficiency.
Of course, you may object, the experimental animals are hogs, not humans, and it is not apparent that we owe hogs what we owe humans, namely, the duty not to be treated as economic pawns. By way of response to this objection, I start with the obvious fact that all living things have basic biological needs (BBNs). BBNs vary by species and, perhaps, even by individual. But in all cases, BBNs are needs that must be met if an individual's welfare is not to be thwarted.

What are some typical human BBNs? To be able to ingest sufficient amounts of uncontaminated protein and water without undue pain; to be able to eliminate bodily wastes without wasting half the day doing it; to be able to maintain sufficient psychological equilibrium that we are able to fall asleep at night; to have access to sufficient open space that we can accelerate our heart rates to one hundred odd beats per minute for half an hour three times a week; to possess a backbone and neck muscles strong enough that our heads do not need external support; to have an immune system not vulnerable to common air borne viruses.

If we are born with a medical condition that deprives us of the ability to have one of our basic needs met, we are the worse off for it, but we cannot necessarily say someone has harmed us. If, on the other hand, our unfortunate condition is the result of someone's having injured or deprived us, or having injured the fertilized egg we once were, then the offending person has harmed us, done us a moral wrong. I will call this principle (1):

(1) It is (morally) wrong to deprive an individual of something it must have if its BBNs are to be met.

Notice it is $A$ who is wronged, and not someone or something else. This means that the principle can only apply to beings with a welfare that may be promoted or harmed. There are, of course, many things in the world without welfares, and such things cannot be directly harmed. Examples include natural objects, like mountains and piles of sand, and human artifacts, like bridges and computer printers. You might harm the owner or user of these things by mishandling the object, but you cannot harm the object, because natural objects and artifacts do not have a good of their own. So (1) does not apply to things, because things are not individuals, do not have biological needs, lack intrinsic value, and have no good or welfare of their own. ${ }^{7}$

Individuals are animated beings, beings that exhibit goal-directed behavior in which the goal or principle 
of movement is internal to the being. Humans are individuals, but fingers are not; hogs are individuals, but a serum with hog growth hormone in it is not; tomato plants are individuals, but their fruit is not. Here an obvious problem with (1) surfaces. If the principle were true, we could not justifiably sever the head of a cabbage from its root in order to eat it. So doing would deprive an individual $A$, the cabbage, of something $A$ needs in order to have its basic biological needs met. ${ }^{8} \mathrm{I}$ trust our common intuition here, that killing cabbages in order to feed ourselves is morally permissible and, more generally, that there are many individuals, including all onions and cabbages, toward which we do not possess even a prima facie duty not to deprive them of things they need to have their BBNs met.

What distinguishes individuals that may be killed from individuals that may not be killed?

I think it is, roughly speaking, consciousness, by which I mean the capacity to take an interest in things in your future. I understand "the capacity to take an interest" in the way many others have: $S$ has the capacity to take an interest in $X$ if and only if $S$ has feelings of well-being that may be affected by $X .{ }^{9}$ Obviously, cabbages are not conscious in this sense, because they lack feelings. I feel confident that cabbages lack feelings because they lack the hardware necessary to have feelings, namely, a brain or a central nervous system. Lacking feelings, they lack the capacity to take an interest in things in their future, or even to have a future. Thus, individual $A$ in the plant kingdon may justifiably be deprived of something it must have if its BBNs are to be met because, even though that individual has BBNs, it does not have consciousness. Having no feelings, no capacity to take an interest in things in its future, it cannot be harmed by depriving it of a future. It is not morally wrong, even prima facie, to kill plants on the grounds that we thereby directly harm them. ${ }^{10}$

We must amend (1), therefore, to accommodate the claim that it is not always prima facie morally wrong to kill individuals. I offer, then, (2):

(2) It is prima facie (morally) wrong to deprive a conscious individual $A$ of the things it must have if its BBNs are to be met.

Combining (2) with

(3) The Beltsville experiments deprived individual hogs of things they need to have their BBNs met, and

(4) Hogs are conscious individuals,

gives the conclusion,

(5) It was prima facie (morally) wrong to deprive the Beltsville hogs of the things they needed to have their BBNs met.

Now, some will want to contest (4) and argue that pigs are not conscious individuals. If pigs are more like bridges, i.e., human artifacts, than like children, then we can no more harm a pig by unintentionally breeding it to have a bad body than we can harm a bridge by unintentionally designing it to lack earthquake sustaining power. On the dominant view in Western cultures of nonhuman animals, animals are more like human artifacts, with instrumental value only, than like human beings, with intrinsic value. But pigs are clearly different from bridges, not only because they can move themselves around, experience pain and pleasure, and lead social lives, but also because there are things pigs must have in order to have their BBNs met. If a pig's bone structure is unable to bear its weight, if its sensory systems are unable to give it reliable information, if its immune functions fail to protect it from common diseases, then the pig will lead a deprived life, unable to engage in the goal-directed behaviors characteristic of its species. It will, variously, not be able to eat or mate or root or play with or care for its young or establish a social order or investigate its environment. The pig itself will fare poorly if it does not have the things it needs to have its BBNs met. If scientists engineer pig embryos that develop into individuals with deformed bodies or poorly developed brains, they have harmed the pig. Whether they do this intentionally or unintentionally should bear on how much culpability we assign to the scientists, but it should not affect the question of whether the pigs themselves have been harmed. So this objection to (4) fails.

Again, one might grant that pigs are individuals and have BBNs, but insist that pigs are unable to take an interest in anything that may affect their future wellbeing. If so, then they, like cabbages, are not conscious individuals, and so cannot have a right not to be deprived of things they need to have their BBNs met. I believe this criticism is wrong, and I will argue that pigs are able to take an interest in some things. But I want to 
avoid the language of animal rights, because the tradition of rights talk is inimical to the sort of moral attitudes I wish to encourage. Rights talk encourages us to think of the moral sphere as an arena of atomistic units warring with each other to defend turf against invaders. I want to encourage views of the moral sphere in which individuals are construed more interdependently, engaged in projects that are more cooperative than competitive. But I must confess that I have a difficult problem, to avoid the individualism of rights language without tearing down the legal and philosophical fence around individuals which rights language has so admirably erected. I think the way to do this is to try to show that the notion that "it is wrong to deprive a being that can take an interest in having its BBNs met of the things it needs to have its BBNs met" is a primitive notion. That is, while you can give examples of the wrong that obtains when an individual is deprived, you can do nothing more by way of giving reasons that it is wrong than telling stories. There is no further justification that can be offered for why it is wrong to deprive an individual, but, fortunately, there is no further justification needed. Let me explain.

Ethical reflection means giving reasons for our judgments. When we say $x$ is wrong, others are justified in asking us why we think that. When we give a reason, that reason may be formulated as a general moral principle. But our partners may want to know why that principle is true, and may justifiably ask us to ground our reasons for our decisions in some more basic, ultimately vindicating, reason. The work of ethics proceeds this way, with claims being grounded in reasons, and reasons in principles, and principles in theories.

But the dialectic of ethics does not go on forever; at some point we reach what is, for us, the true, ultimately vindicating ground of our reasoning. When we reach this ground, others will ask us why we rest on that ground, and we may be tempted to try to provide a reason. We should resist this temptation, because, if we have truly reached bedrock, there is nothing further for us to say. Wittgenstein once remarked that the most difficult part of justification in philosophy is to recognize a justification as a justification, and to stop.

I can tell you why I think hogs are individuals, and I can tell you why I think harming individuals by depriving them of the basic things they need is morally wrong, and I can give you examples of cases I think involve harm to individuals and cases I think involve no harm to individuals. But I cannot tell you why I think harming individuals is morally wrong. If you tell me that you see no moral wrong in harming individuals, I have three responses open to me. I can first ask you if you are serious, and try to decide whether I think you are speaking in good faith. If.I decide you are serious, I can, second, tell you stories of deprivation. If after several rounds of stories, told in increasingly graphic detail, I decide that you are still serious about the claim that you see no moral wrong in harming individuals, then I have no option but to decide that you have not been brought up in the right way, and that you may be dangerous.

My claim is that the following idea is a primitive notion, which reasonable persons, once they understand it, must accept: "To harm an individual by depriving it of things it needs to have its BBNs met is prima facie morally wrong." If I am correct, then I can use this primitive notion in place of rights talk. That is, wherever philosophers have justifiably ascribed a basic "right" to $r$ in order to underscore the importance of some entitlement an individual has, or some duty others have toward the individual, I want to say that reasonable persons brought up correctly who understand what it would mean to deprive the individual of $r$ also understand and accept the primitive notion that "depriving the individual of $r$ is prima facie morally wrong." And that is all we can say, or need to say, about the matter.

If the argument about primitive notions works, I can offer a strong protection for individuals without recourse to rights talk. And that would allow us to show why we have strong duties not to deprive conscious beings of things they need to have their BBNs met. As Michael Tooley has shown, you cannot have a right to something unless you are capable of taking an interest in it. ${ }^{11}$ You cannot take an interest in something unless you are conscious. Thus, only conscious beings, which is a subset of the class of all individuals, are candidates for the strong protections traditionally formulated in rights language. So it remains for me to say why I think hogs are conscious.

My reason for thinking hogs can take an interest in something is the same as my reason for thinking my four-month-old daughter can take an interest in something. In my daughter's case, my belief is based on inferences drawn from observations of her behavior. I remember watching Krista's eyes follow a mobile slowly turning over her crib. Her lids would open slowly 
after her nap, wander around the room, and then fix on the motions above her. I surmised she was "taking an interest" in the mobile because her eyes would sometimes stray toward me, but she would shut out the distraction, even as I strained to get her attention, focusing once again on the revolving colors.

In the hog's case, my belief is based on similar inferences. I say to my uncle, an lowa farmer, "That old sow really took an interest in the tire we threw in there." When I say "took an interest," I mean it in exactly the same sense I apply to my daughter. Consider the behavioral signals each gives, the level of visual and mental focusing going on, and the kinds and grounds of inferences I make on the basis of those signals. All of these things are identical in the two cases. I see the hog's eyes open as the tire sails in; I see the animal slowly rise to face the foreign object; I watch as he cautiously approaches it, snorting and backing at irregular intervals. I surmise, as I watch him spend the rest of the morning intently nosing the tire treads, oblivious to me and to his pen mates, that his attention has been captured by the tire. What more simple or elegant or efficient explanation is there than to say, "the pig has taken an interest in" the object?

This point, being the crux of my argument, bears underscoring with other examples. Boars can take a monogamous interest in a single gilt coming into heat, in a knot hole knocked through a pine board, and in the bristles of another pig's back. They can take an active interest in people, and they can, if the Hollywood animal trainer Frank Inn is to be believed, take an active interest in ignoring people. Inn reportedly said: ${ }^{12}$

You can force a dog, a chimp or a horse to do something, but a pig, no. Pigs won't take punishment. Reprimanding will work with a dog, but with a pig, never. If you reprimand a pig he won't like you, won't respond to you and won't even take food from you. You can see temper in pigs. If I scold them, they scold right back. ${ }^{13}$

If an individual has the capacity to take an interest in something, it must be capable of losing interest in something, too. We usually lose interest when we become bored, when the thing occupying our attention no longer intrigues us. That happens when something that once intrigued us no longer presents new opportunities or facets to our imagination. Our imaginations, of course, are not infinitely plastic, and the things that will continue to engage our fancy over a long period of time fall within limits drawn by our genetic background, social upbringing, and professional training.

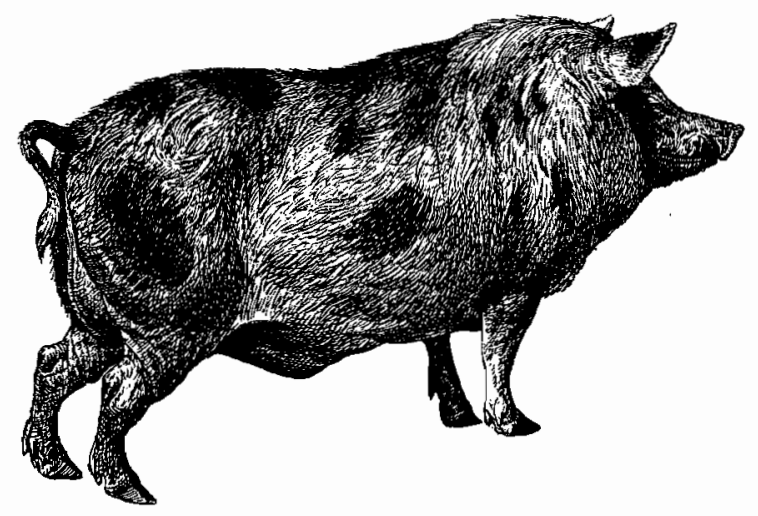

Pigs can lose interest in things. In one experiment, hogs were trained to carry coins from one end of their pen to the other, and to deposit them in a bank. Researchers found that the animals quickly progressed to a stage where the animals would carry four or five coins before needing reinforcement. As they put it, "Pigs condition very rapidly," or, as I would prefer to put it, pigs have a tremendous capacity for becoming interested in things. But, being intelligent, pigs also have a high threshold of boredom. Unless a new object or behavioral stimulus has some relationship to the basic wants and drives of a pig, we can predict that the pig's interest will wane. In a development that could only have been surprising for scientists committed to a particular paradigm, that is what happened in this case. After a period of several weeks, the experimental animals stopped performing the chore they had been "conditioned" to do. 
This particular problem behavior developed in pig after pig, usually after a period of weeks or months, getting worse every day. At first the pig would eagerly pick up one dollar, carry it to the bank, run back, get another, carry it rapidly and neatly, and so on, until the ratio was complete. Thereafter, over a period of weeks the behavior would become slower and slower. He might run over eagerly for each dollar, but on the way back, instead of carrying the dollar and depositing it simply and cleanly, he would repeatedly drop it, root it, drop it again, root it along the way, pick it up, toss it up in the air, drop it, root it some more, and so on. ${ }^{14}$

The researchers described the pig's actions as "problem behavior" resulting from a breakdown in "conditioning." We might describe it more accurately by calling it a natural loss of interest in objects and stimuli not consistent with the pig's basic biological needs and basic biological wants. The pigs, being pigs, were more interested in rooting the coins than in putting them in the bank. The behaviorists' conclusion bears citing:

We thought this behavior might simply be the dilly-dallying of an animal on a low drive. However, the behavior persisted and gained in strength in spite of a severely increased drive-he finally went through the ratios so slowly that he did not get enough to eat in the course of a day. Finally it would take the pig about 10 minutes to transport four coins a distance of about 6 feet. This problem behavior developed repeatedly in successive pigs... [We concluded] that these particular behaviors to which the animals drift are clearcut examples of instinctive behaviors having to do with the natural food getting behaviors of the particular species. ${ }^{15}$

To call the pigs' behavior "instinctive," of course, begs the question of whether the animals are beings with mental powers comparable to those of, say, a human infant. An alternative explanation is that the hogs' behaviors were clear-cut examples of this species' ability to take an interest in, and then to lose interest in, novel environmental conditions. In saying this, I intend the phrase, "take and lose interest in," in exactly the same sense I intend when I use it of my daughter.

Hogs can take an interest in things in their environment, and so they have a future. They not only have BBNs, but they have a welfare, a good, that may be promoted or harmed. It is a primitive notion that it would be morally wrong to harm an infant by depriving it of the things it needs to have its BBNs met. In exactly the same way, it is a primitive notion that it is morally wrong to harm a pig by depriving it of things it needs to have its BBNs met.

Even if the moral wrong at Beltsville was done originally not to adult animals but to ova, and even if the harm was unintended, those facts should no more cause us to say that the animals themselves were not wronged than we should say the girl an embryo will become is not wronged by unintentional harm resulting from manipulating the ovum she was at the embryonic stage. It was wrong for the Beltsville scientists to engineer pig embryos for the reasons officially circulated, and it is morally indefensible for them to continue the research program without reasons of a very different sort. ${ }^{16}$

\section{Notes}

${ }^{1}$ For transgenic mice, see R. D. Palmiter, R. L. Brinster, R. E. Hammer, M. E. Trumbauer, M. G. Rosenfeld, N. C. Brinberg, and R. M. Evans, "Dramatic Growth of Mice that Develop From Eggs Microinjected with MetallothioneinGrowth Hormone Fusion Genes," Nature 300 (1982): 611 615 ; R. D. Palmiter and R. L. Brinster, "Transgenic Mice," Cell 41 (1985): 343-345; and R. D. Palmiter, G. Norstedt, G. E. Gelinas, R. E. Hammer, and R. L. Brinster, Science 222 (1983): 809. For transgenic swine, see R. E. Hammer, V. G. Pursel, C. E. Rexroad, Jr., R. J. Wall, D. J. Bolt, K. M. Ebert, R. D. Palmiter, and R. L. Brinster, Nature 315 (1985): 680; C. A. Pinkert. V. G. Pursel, K. F. Miller, R. D. Palmiter, and R. L. Brinster, Journal of Animal Science 65 (Suppl. 1, 1987), Abstr.; and C. A. Pinkert, "Gene Transfer and the Production of Transgenic Livestock," Proceedings of the U. S. Animal Health Association (in press): 122-133.

2 "Transgenic"refers to animals with "foreign" genes, genes from species with which they cannot breed naturally. The changes in the germ line are accomplished via recombinant DNA techniques.

${ }^{3}$ Michael W. Fox, "Genetic Engineering and Animal Welfare." Applied Animal Behaviour Science 22 (1989), 
p. 107. "Pleiotropism" is a biological term meaning "multiple." In this context, it refers to the many mechanisms involved in the genes' control of the physical make-up of the animal.

${ }^{4}$ Of 29 founder pigs, 19 expressed either human growth hormone or bovine growth hormone. Among those exhibiting long-term elevated levels of bGH, health was generally poor: "the pigs had a high incidence of gastric ulcers, arthritis, cardiomegaly, dermatitis, and renal disease." Vernon G. Pursel, Carl A. Pinkert, Kurt F. Miller, Douglas J. Bolt, Roger G. Campbell, Richard D. Palmiter, Ralph L. Brinster, Robert E. Hammer, "Genetic Engineering of Livestock," Science 244 (16 June 1989): 1281.

${ }^{5}$ R. E. Hammer, V. G. Pursel, C. E. Rexroad, Jr., R. J. Wall, D. J. Bolt, K. M. Ebert, R. D. Palmiter, and R. L. Brinster, "Production of Transgenic Rabbits, Sheep and Pigs by Microinjection," Nature (London) 315: 680-683. Cited in Michael Fox, op. cit., 1989, p. 107.

${ }^{6}$ Pursel, et al., op. cit., 1989, p. 1281.

${ }^{7}$ Consider a mechanical engineer who unwittingly designs a highway bridge that cannot sustain the vibrations of an earthquake. The engineer does not necessarily do something morally wrong by designing such a bridge. To see why, imagine that her plan is executed; the bridge is built, and traffic proceeds over it. The bridge sustains the ordinary number of stresses, and some serious cracks, but the cracks never break, no earthquake ever strikes, and the structure serves its purpose adequately.

Shall we say that the engineer has done something morally wrong? I think not, because no harm has been done to any moral agent or patient, and society's interest in transporting itself efficiently and safely across a chasm has been served. Should an earthquake strike, the bridge fail, and a motorist be injured, the engineer would then be a candidate for moral blame. But it is not until some agent is harmed that the engineer becomes culpable, because we cannot make sense of the idea that the engineer could harm the bridge itself. If we say that a good bridge is one that will withstand an earthquake, and a bad bridge one that will not, we do not mean good and bad in a moral sense. Bridges, good or bad, can take no interest in their welfare. If we say that it is not in the bridge's interest to have its cracks repeatedly filled with water and frozen, we do not mean "interest" here in the sense required to give the bridge a welfare.

${ }^{8}$ For an argument that plants are individuals, have needs, and biological interests, and that this qualifies them for direct moral consideration, see Gary E. Varner, "Biological Functions and Biological Interests," The Southern Journal of Philosophy 28 (1990): 251-270.

${ }^{9}$ Cf. S. F. Sapontzis, Morals, Reason, and Animals (Philadelphia: Temple University Press, 1987), p. 74. Sapontzis gives credit to Leonard Nelson for this analysis.
See Nelson, A System of Ethics (New Haven: Yale University Press, 1956), pp. 136-144.

${ }^{10}$ However, I believe that there are other grounds, of an environmental sort, that can provide reasons that it is prima facie wrong to kill plants. These environmental grounds show that some significant good is harmed when plants are killed willy-nilly, without good reason. But that good does not include the welfare of the plant itself.

${ }^{11}$ Tooley, discussing the alleged right to life of fetuses, gives what he calls the "particular-interests principle," which draws on Joel Feinberg's general "interest-principle." Tooley's principle states "It is a conceptual truth that an entity cannot have a particular right, $\mathrm{R}$, unless it is at least capable of having some interest, $I$, which is furthered by its having right $R$." Michael Tooley, "In Defense of Abortion and Infanticide," in Joel Feinberg, ed., The Problem of Abortion, 2nd. ed. (Belmont, CA: Wadsworth, 1984), p. 125. Tooley's example of the principle is that "an entity cannot have a right to life unless it is capable of having an interest in its own continued existence" (p. 132).

Unlike some species, humans typically have the capacity to take an interest in having our BBNs met. Because most of us are sentient and conscious, we can know that having our BBNs met is good for us, and that not having them met is bad for us. Most humans are conscious of their basic needs, can know whether their BBNs are being met, and can ascertain whether their lives are going well or poorly. Most prefer to live in conditions in which we are able to feed ourselves, keep ourselves warm, and enjoy supportive and stimulating companions.

${ }^{12}$ Because hogs are such social creatures, writes William Hedgepeth, they "appear, in general, to recognize that whatever it is they think they are, they are at least all together in being that thing... And because they sense this, they invest all their brief born days with those universally accessible traits that make their lives mutually comfortable: decency, candor, common sense, self-reliance, courage, integrity, love, charity and casual ecstasies," Hedgepeth, p. 137.

${ }^{13}$ Quoted in William Hedgepeth, The Hog Book (New York: Doubleday, 1978), p. 111.

${ }^{14}$ Keller Breland and Marian Breland, "The Misbehavior of Organisms," American Psychologist 16 (1961): 683, reprinted in Robert W. Hendersen, ed., Learning in Animals (Stroudsburg, PA: Hutchinson Ross, 1982), p. 286.

${ }^{15}$ Breland and Breland, p. 683.

${ }^{16} \mathrm{I}$ read an earlier version of this paper at the Iowa Philosophical Society in November, 1990. My research was supported by the Bioethics Program at Iowa State University. I am grateful for comments from Ned Hettinger, Steve Sapontzis, and colleagues in the Philosophy Department at Iowa State. 